\title{
The death of North Sea fish during the winter of 1962/63, particularly with reference to the sole, Solea vulgaris
}

\author{
Peter M. J. WoOdhead \\ Fisheries Laboratory, Lowestoft, England
}

KURZFASSUNG: Das Absterben von Nordseefischen während des Winters 1962/63 mit besonderer Berücksichtigung der Seezunge Solea vulgaris. Während des kalten Winters 1962/63 kam es zu Fischsterben in weiten Bereichen der südlichen Nordsee. Es wird über das Ausmaßs dieses Sterbens, die betroffenen Areale und die geschädigten Arten berichtet und die gefundenen Daten zur Meerestemperatur in Beziehung gesetzt. Die Sterberate war geringer als während des harten Winters 1946/47, aber wohl ähnlich wie die im Winter 1928/29. Das betroffene Areal war 1963 größer als in den früheren Jahren. Viele Fische sind offenbar direkt durch die Kälte getötet worden. Dieser Umstand wird unter Berücksichtigung der Physiologie der betroffenen Arten diskutiert. Zweifellos wurden viele Fische auch durch bakterielle Hautinfektion getötet.

\section{INTRODUCTION}

Low temperatures have frequently been reported as causing death of fish in the sea. Perhaps the most familiar example is the catastrophic mortality which occurred amongst the population of the American tilefish, Lopholatilus chamaeleonticeps GoOde \& BeAN, off the Massachusetts coast in 1882 (Jordan \& EvERMan 1902) when innumerable dead fish were found over an extensive area of the sea surface as cold water covered the banks. During severe winters the temperatures in shallow seas may fall abnormally low and cause mortalities; over the last eighty years there have been several reports of this happening in the Gulf of Mexico and on the Florida coast (Willcox 1888, Finch 1917, Storey \& Gudger 1936, Mrller 1940, Galloway 1941). Mortalities amongst the fish populations in European waters have similarly been observed during cold winters, particularly in the shallow areas of the North Sea to the south of the Dogger Bank and in the Baltic (Dannevig 1930, Johansen 1929, Lumby \& A tKinson 1929, Simpson 1953).

The very prolonged period of cold weather during the winter of 1963 led to exceptional cooling of the waters of the southern North Sea, and by late February fishing vessels were reporting dead fish in their catches. Dead fish were also recorded along the coasts of the English Channel (WOODHEAD 1964a). The areas of fish mortalities in the North Sea were surveyed throughout the cold period, with the co-operation of the fishing fleet. The sequence of these events in the North Sea is described in the present paper, and some of the causes of death are examined. 


\section{THE ASSEMBLY OF THE DATA ON FISH MORTALITIES}

Sea temperatures began falling rapidly at the end of December, and continued to decline during January; by early February it was apparent that temperatures were approaching the low levels recorded in 1947, and it was thought that if the cold weather continued much longer heavy mortalities would occur amongst the fish populations. On February 12th a special notice was issued to the skippers of the English North Sea trawling fleet describing the effects of prolonged cold upon the fish, and predicting that if the cold spell continued dead fish could soon be expected to appear

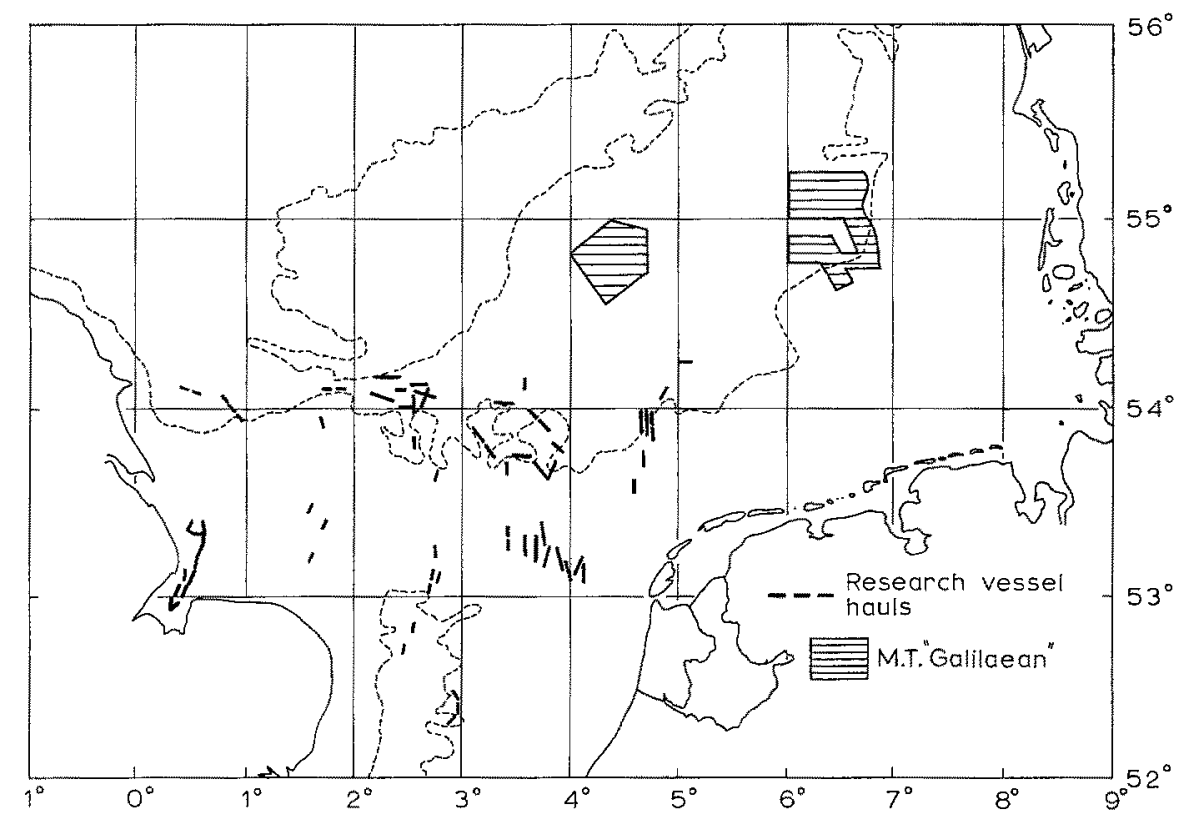

Fig. 1: Trawl surveys made by the fishery research vessels, and the areas reported by the M. T. "Gallilean"

in their catches. In order to obtain a good record of the expected mortalities, the skippers were asked to co-operate in the investigation, by reporting on recording sheets, attached to the notice, the occurrence of dead fish.

Due to lack of sufficient interest amongst many of the fishermen, the number of reports submitted concerning dead fish was small in relation to the large North Sea trawler fleet. However, the skippers who did report had frequently taken some trouble to make accurate accounts; some also reported two or three cruises in the same area, providing considerable help in assessing the sequence of the changes.

A factor which certainly reduced the number of fishing reports returned during the cold period was the misgivings of some fishermen who believed that the enquiry might be initiated in association with food inspection to discover whether fish caught dead were being landed for public sale at the ports. These fishermen usually strenuously denied catching any dead fish when questioned, although some later admitted 
that they had indeed caught dead fish when the true purpose of the investigation was explained. It is unfortunate that these unfounded suspicions arose; LUMBY \& ATKINsON encountered similar anxieties amongst fishermen during their investigations in 1929.

Although the response to the request for reports was smaller than had been anticipated, the number of skippers who made reports, sometimes in considerable detail, provided sufficient information to give reasonable cover of the southern North Sea from latitude $52^{\circ} \mathrm{N}$ to the northern edge of the Dogger Bank. The fishing reports were supplemented by personal interrogation of some skippers and mates of trawlers at the ports of Grimsby and Lowestoft. The information gained from these fishing reports, and also from questioning the trawler officers, differed considerably in the amount of detail given. Some skippers reported catches of dead fish in all trawl hauls, others gave two or three typical hauls per day, yet others gave estimates for each day's fishing or for the whole cruise. A few skippers also offered valuable comments on the changes which they had observed between consecutive cruises. Different boats, working in the same areas, reported varying catches of dead fish, but despite the heterogeneity of the data, a surprising degree of general agreement occurred and it was possible to distinguish areas of high and low mortality and to follow their development with time.

Independent trawling surveys were made throughout the area with the Ministry of Agriculture, Fisheries and Food research vessels "Clione" and "Platessa"; these are shown in Figure 1, together with the areas fished by Skipper G. W. Smrxt of the trawler "Gallilean" (G. Y. 603), who recorded dead fish with such meticulous care that his report, together with the fishing chart which he submitted, has been included with those from the research vessels. These surveys were of particular value in providing separate detailed assessments for comparison with the fishing vessel reports from the same areas.

\section{THE SPECIES KILLED}

It is well known that at any time of year some dead fish may be caught which have been rejected by other fishing vessels or have escaped injured from their nets. However, it is quite clear that even in areas where mortalities were low, the dead fish caught were extraordinary, and that many of these fish had not been rejected as being too small for landing. For instance, Skipper G. W. SMITH of the trawler "Gallilean", fishing in the vicinity of the White Bank, observed that "all dead fish are sizeable and could have been saved" (i. e., were of a marketable size). Large dead soles were frequently reported over wide areas, and since they would command high prices on the fish markets they would not have been rejected. Some fish were killed by a skin infection during the winter, and this again identified the fish as extraordinary. High mortalities occurred over wide areas.

In the inshore areas dead and dying conger eels (Conger vulgaris) were frequently reported from the beginning of February, and since temperatures continued to fall for scme weeks after this, the mortality rate must have been high for this species. Offshore the soles (Solea vulgaris) undoubtedly suffered the highest mortalities and dead soles were caught throughout most of the area of the North Sea to the south of the Dogger 
Bank at some time during February to April. Other species which died in offshore regions included dabs (Pleuronectes limanda), plaice ( $P$. platessa), whiting (Gadus merlangus), gurnards (Trigla sp.,) and occasional brill (Rhombus laevis) and turbot (R. maximus); small numbers of dead cod (G. morbua) were also reported.

In 1947 there appeared to be some differences in the distribution of mortalities between species, but, from the data for the present winter, dead fish were caught in approximately the same areas apparently irrespective of species (apart from the conger

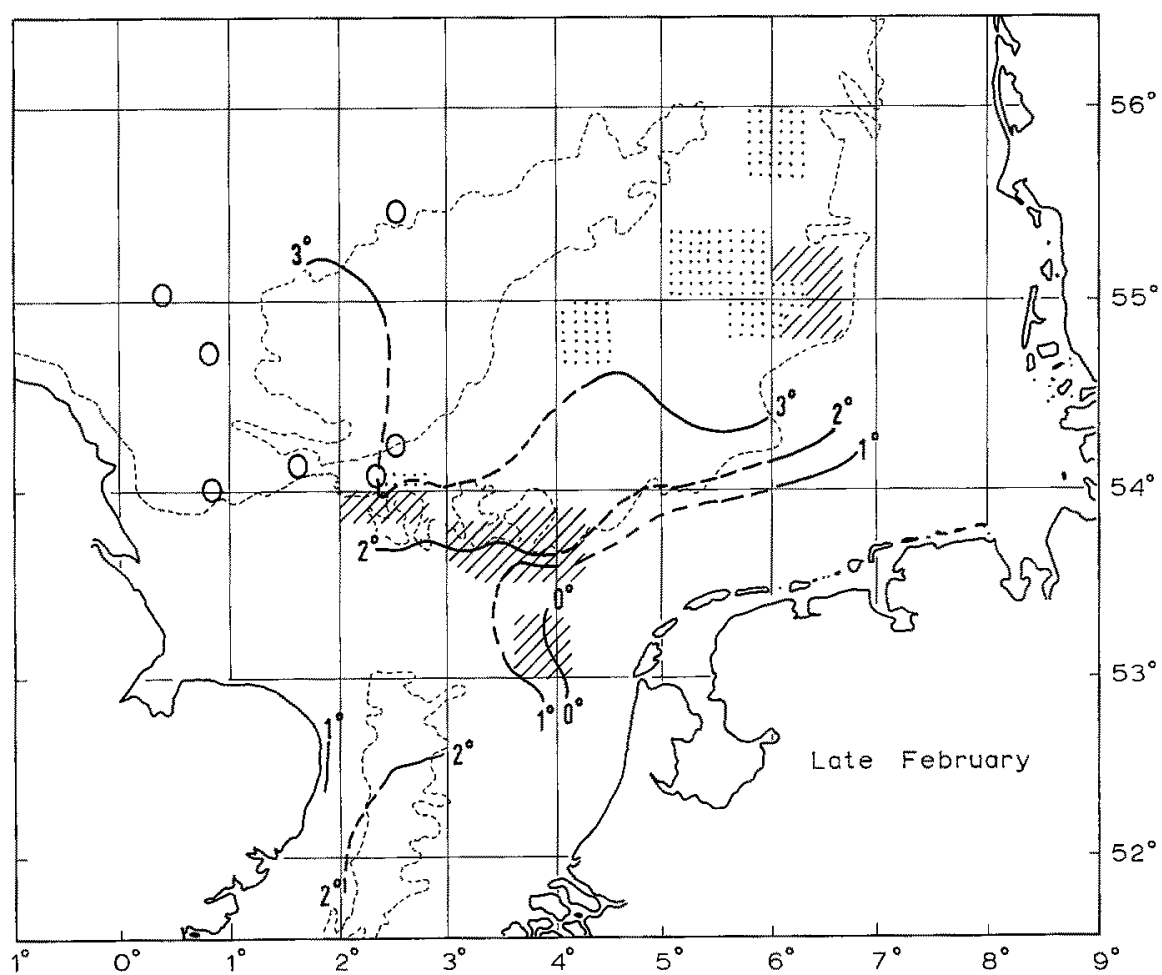

Fig. 2: The distribution of dead fish in late February; circles: negative reports; dots: occasional dead fish in trawl hauls; hatching: few dead fish in every haul; cross-hatching: six or more dead fish per haul; v's: very high mortalities reported

eels, found in the coastal areas). Soles predominated in numbers, but a few dead plaice were frequently caught in the same areas. In a preliminary publication (WOODHEAD 1964 a) it was stated that dead plaice were frequently reported at the rate of one or two dead fish per trawl haul. Reconsideration of the more extensive data which have now become available shows that although plaice mortalities remained generally at this low level, some reports mentioned catches containing ten to fifteen dead plaice; these reports were most frequent in the colder areas. One or two dead cod were often reported in the trawl hauls throughout the area, but large numbers were never encountered; very few dead cod were taken in the areas to the west of the Dogger Bank. 
Dead dabs were mentioned in the reports but they appeared to be much less regular in distribution, occasional fairly large catches of dead fish being made. SIMPSON (1953) remarked upon similar reports for dabs during the winter of $1946 / 47$. Records of dead whiting were also rather sporadic, occurring as infrequent catches, whilst dead gurnards were seldom mentioned at all except as one or two isolated high catches. These last three species are all of low commercial value on the English market and would therefore be expected to excite less comment from the fishermen. Furthermore,

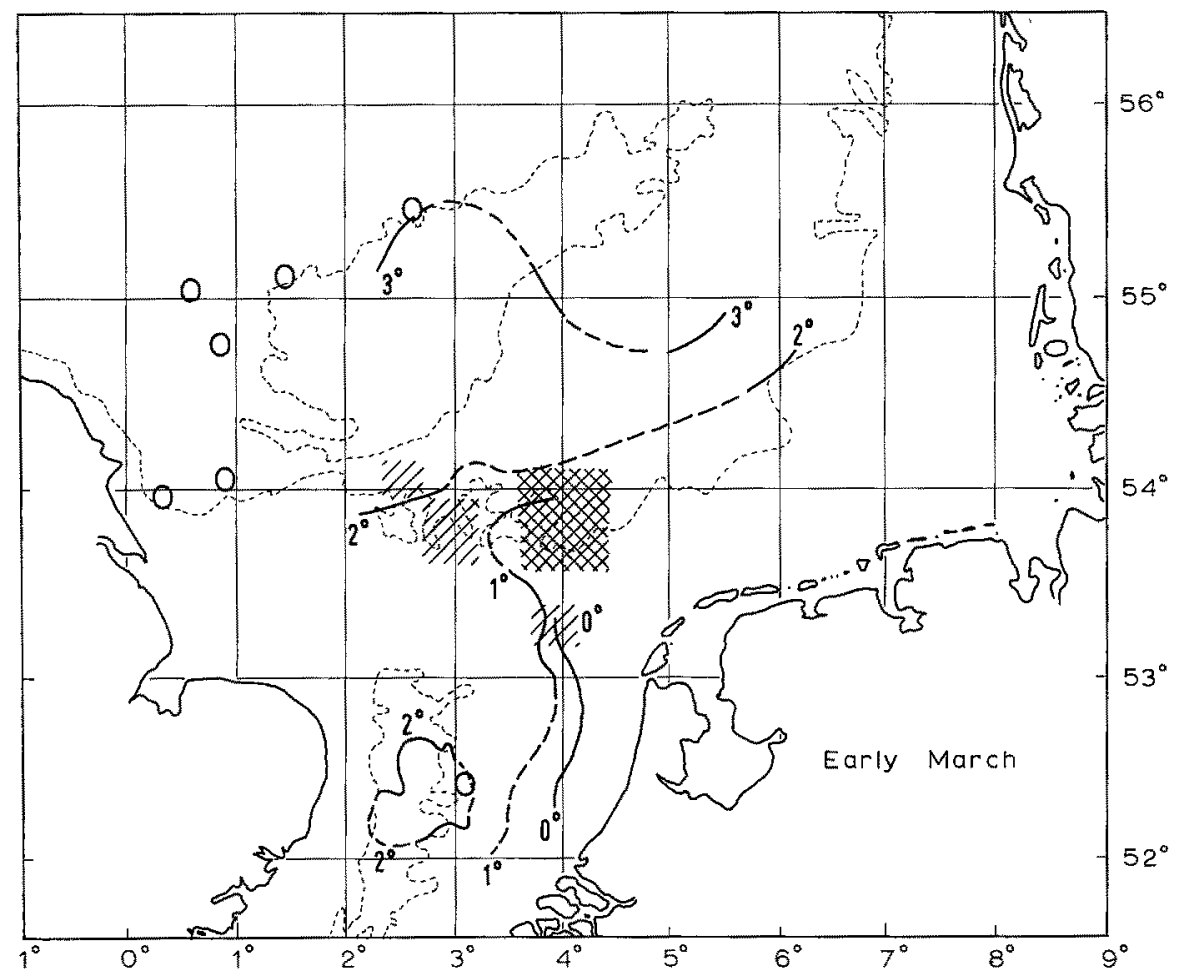

Fig. 3: The distribution of dead fish in early March (key as in Fig. 2)

it would be more likely that when good catches of high-priced fish were being made, as occurred during the winter, these three species might well be thrown back into the sea, and many of them would be killed in the process. It is therefore difficult to assess the exact extent of their deaths due to low temperatures, but from conversations with the trawler officers it seems certain that all three species had suffered abnormal mortalities during the winter; dead gurnards were also caught in the Channel. Some fishermen remarked that few gurnards were being caught, and none were taken in the research vessel hauls, although they are normally common throughout the southern North Sea. It seemed that the gurnards had left the cold water areas; similarly most whiting had left these areas. 


\section{THE SEQUENCE OF MORTALITIES}

The information gathered from the fishing reports, from discussions with fishing officers, and from the research vessel surveys, is sufficient to divide the critical period of mortality into five phases - late February, early, middle and late March, and early April. This progression of mortalities, reaching a peak in mid-March and thereafter declining, is shown in Figures 2 to 6 . In compiling these charts of dead fish distribution, emphasis has been laid on the average numbers of dead fish caught on a fishing ground, rather than upon the frequency of reports from the different areas, since the latter would be related, in part, to the number of vessels fishing a ground. Negative reports have been included on the charts; in some cases these coincided with reports of small numbers of dead fish, and in such areas the level of mortality was probably very low.

Fishing reports were sparse for the area to the east of $5^{\circ} \mathrm{E}$ in March and April, but to the west of this longitude a fairly good cover was obtained. Dead fish began to

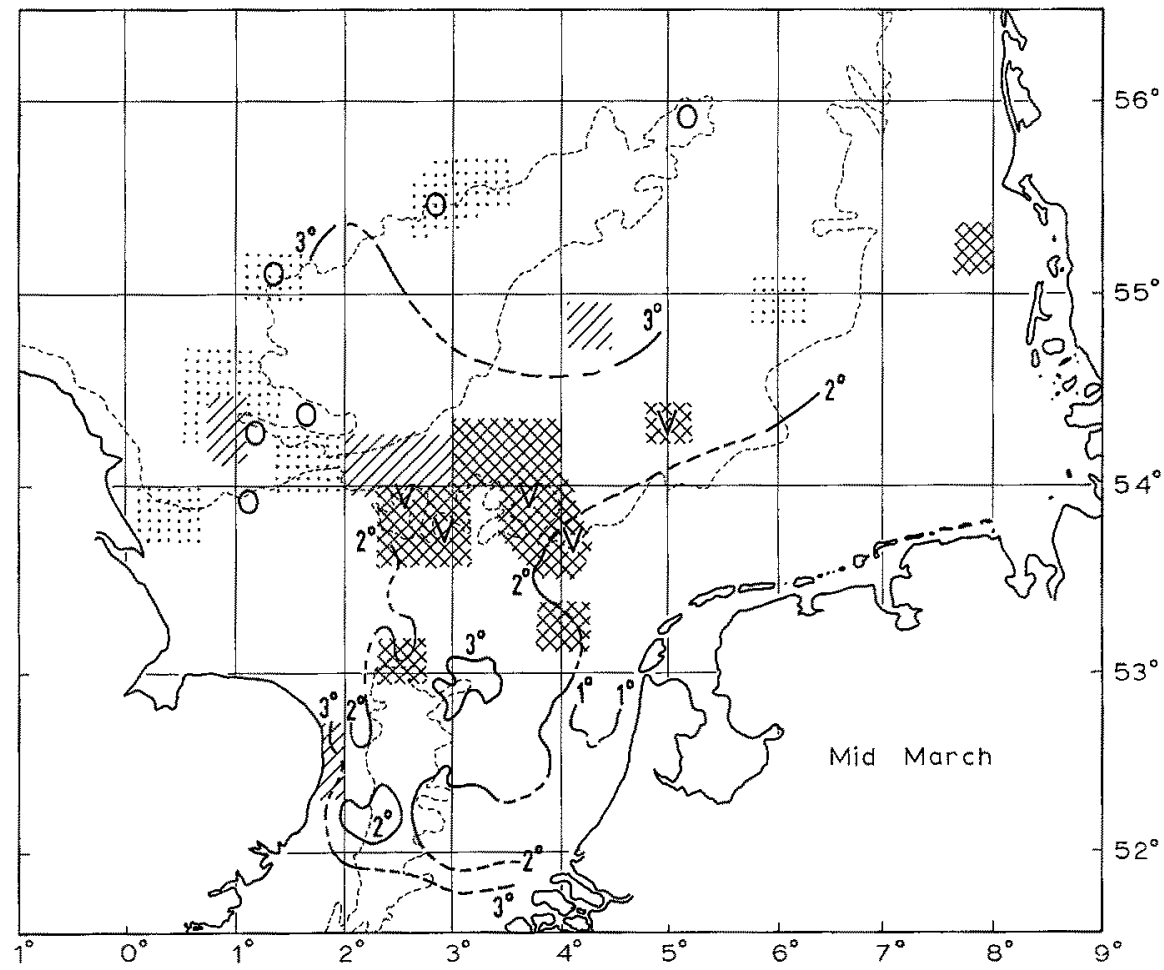

Fig. 4: The distribution of dead fish in mid-March (key as in Fig. 2)

appear in the catches in the third and fourth weeks of February in the area of the White Bank off the Danish coast, at the south side of the Silver Pits (approximately $54^{\circ} \mathrm{N}, 2^{0}$ to $3^{\circ} \mathrm{E}$ ), and around the "S. 'T. Buoys" and the Cleaver Bank (an area approximately from the Frisian Islands to $54^{\circ} \mathrm{N}, 3^{\circ} \mathrm{E}$ ). This latter area was later to 
become the area of highest mortalities, but the trawlers working there in late February failed to report that they had been catching dead fish and although this was discovered in subsequent discussions, it has been difficult to ascertain the exact degree of mortality. It was therefore possible that the deaths in the area may have already been

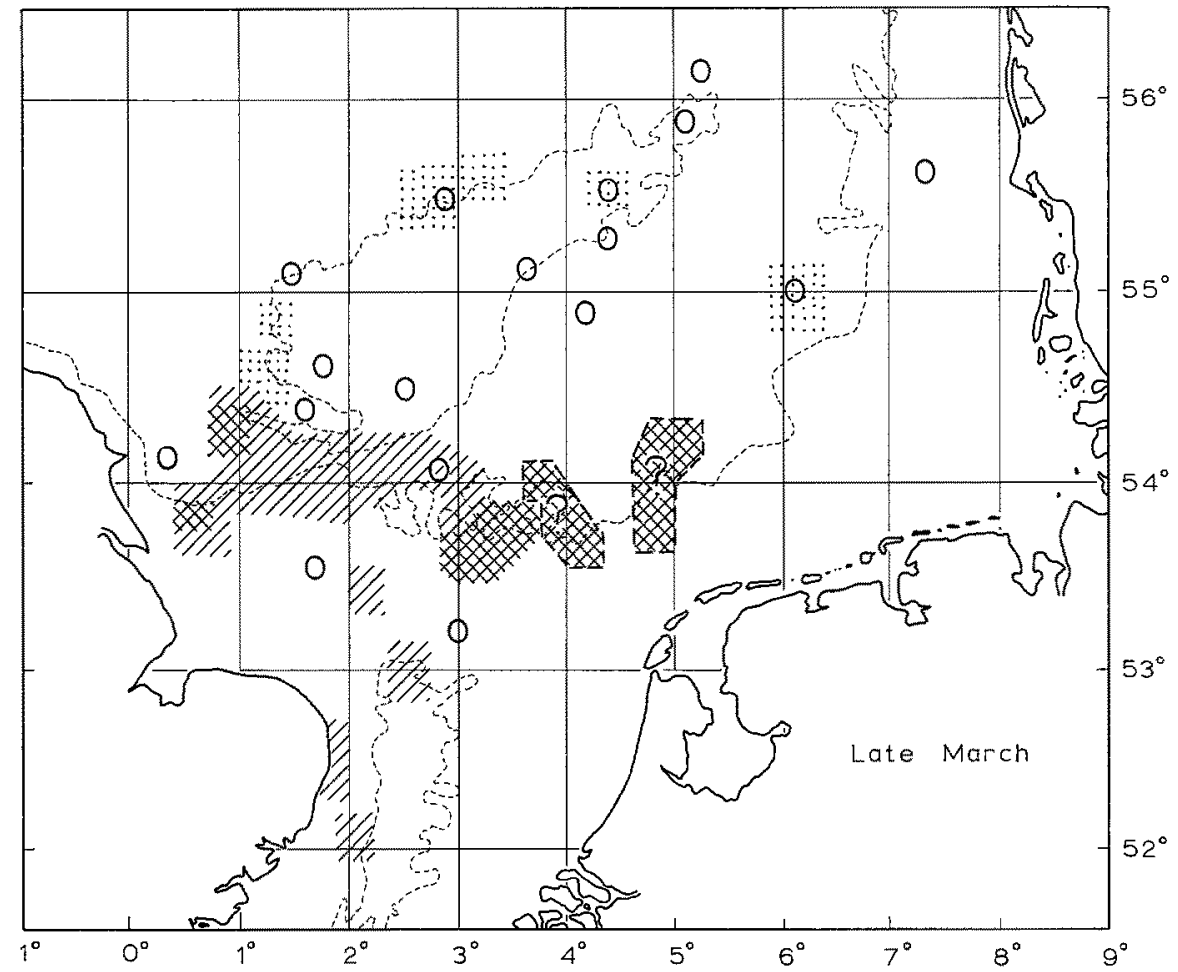

Fig. 5: The distribution of dead fish in late March (kney as in Fig. 2)

higher than indicated in Figure 2; on the other hand the research vessel trawl hauls made there at that time did not reveal very high mortalities.

In March the catches of dead fish increased rapidly in the area between $53^{\circ} 30^{\circ} \mathrm{N}$ and $54^{0} 15^{\prime} \mathrm{N}$, from $2^{\circ} \mathrm{E}$ to $5^{\circ} \mathrm{E}$ (Fig. 3), so that by mid-March a number of trawlers gave estimates of from $10 \%$ to $50 \%$ of the soles dead in some hauls, and boats ceased to fish in the eastern part of the region (Fig. 4). Simultaneously dead fish were reported for the first time to the south-west of the Dogger Bank and off the Yorkshire coast; the mortalities in these areas actually increased in late March when mortalities to the east were apparently declining (Fig. 5). To the south-west of the Dogger Bank, the areas reported as being most affected were around the Hills ground (approximately $54030^{\prime} \mathrm{N}, 0^{0} 55^{\prime} \mathrm{E}$ ) and the Westermost Rough (approximately $53^{\circ} 50^{\prime} \mathrm{N}, 0^{0} 30^{\prime} \mathrm{E}$ ), but mortalities on both of these grounds were never as high as those encountered from the Dutch coast to the Outer Silver Pits. During April the catches of dead fish gradually declined and reports ceased about the middle of the month (Fig. 6). 


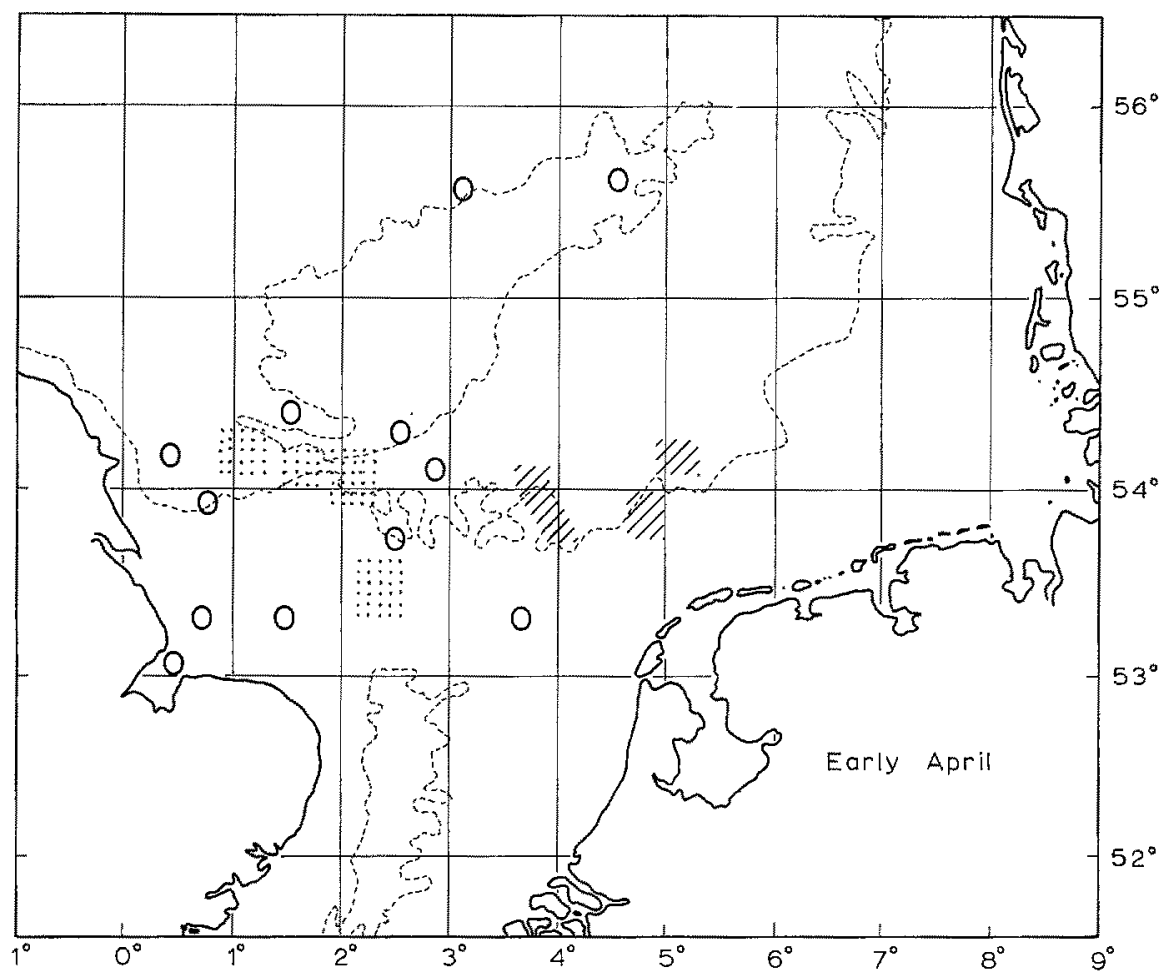

Fig. 6: The distribution of dead fish in early April (key as in Fig. 2)

\section{THE DISTRIBUTION OF DEAD FISH IN RELATION TO THE COLD WATER}

It is of considerable interest to compare the distribution of mortalities with the sea temperatures recorded in these areas. ELLETT (1963) has recently given details of the surface temperatures for most of the North Sea to the south of the Dogger Bank for the period from January until 16th March; these have been incorporated as isotherms in Figures 2 to 4 . The waters of the southern North Sea are normally vertically homothermal (LAEvastu 1962), and this was still found to be the case in the present winter. At a number of hydrographic stations worked by R. V. "Clione" during this period, there were usually only small differences between the temperature at the sea surface and that at the bottom. Thirty-four stations spread over much of the western side of the southern North Sea showed that the water column was homothermal in many cases, or differences only amounted to 0.1 to $0.2^{0} \mathrm{C}$; at only two stations were greater differences observed between the surface and bottom temperatures, 0.35 and 0.60 , both stations being close to the continental coast in water of $0^{\circ} \mathrm{C}$ where cooling was taking place rapidly. It can therefore be assumed that in the offshore areas the surface temperature distributions shown in Figures 2 to 4 were 
closely related to the temperatures at the sea-bed. Lumby \& Atrinson (1929) made the same assumption when considering the hydrographic data for the winter of 1929 .

From the figures, it can be seen that the highest mortalities occurred in areas which had been covered by the $2^{0} \mathrm{C}$ isotherm in early March. Some dead fish were caught over a wider area where temperatures did not fall to $2^{\circ} \mathrm{C}$, although they probably fell below $3^{0} \mathrm{C}$. Unfortunately there is little hydrographic information available as yet for the region south-west of the Dogger Bank, to the west of $2^{\circ} \mathrm{E}$. By the middle of February cold water had formed off the mouth of the River Humber, and the $2^{\circ} \mathrm{C}$ isotherm extended from the coast beyond $1^{\circ} \mathrm{E}$. It seems probable that the cold water later extended much further towards the Dogger Bank, and certainly the $3^{\circ} \mathrm{C}$ isotherm moved well out from the coast and ran across the centre of the Dogger Bank. Cooling also occurred in the shallow water on top of the Dogger, and at a general position $55^{0} 05^{\prime}$ to $55^{0} 14^{\prime} \mathrm{N}, 2^{0} 30^{\prime}$ to $2^{6} 14^{\prime} \mathrm{E}$ temperatures remained at about $3^{\circ} \mathrm{C}$ for nearly ten weeks from January to April (Ellett 1963).

There appeared to a short time-lag between the development of the minimum temperatures during the winter and the records of greatest mortalities, the latter occurring in mid-March in the area which had been covered by the $2^{\circ} \mathrm{C}$ isotherm during the first week of that month. A similar delay in the death of fish ensued in 1947, when reports showed the highest catches of dead soles were made during the second half of March (Simpson 1953), whereas the surface temperatures had reached a minimum at the end of February, and had actually begun rising again in mid-March (VAuX 1953).

\section{COMPARISON WIT'H PREVIOUS SEVERE WINTERS}

During the winters of $1946 / 47$ and $1928 / 29$ abnormal cooling of the waters of the southern North Sea took place and there were high mortalities amongst the fish populations, particularly the soles. Since the areas of high mortality were fairly well documented at those times, by interviewing fishermen in a manner similar to that of the present investigation, it is of considerable interest to compare them with the mortalities in 1962/63.

The main region of high mortalities occurred off the Dutch coast in all three winters. It is apparent from Simpson's report for 1947 that very large numbers of soles were killed in "the second half of March ..., many fishermen (were) reporting at least $50 \%$, and many $100 \%$, dead from the whole area of the cold tongue" (Simpson 1953), so that by the end of March the water had become polluted. Nothing like this occurred in 1963. Although some high mortalities were reported in the cold area during mid-March 1963, these reports were made by only a small number of boats and there was no evidence of the sea becoming polluted. Unfortunately these boats gave little detail for individual trawl hauls, but it seems probable that some catches of from 10 to $30 \mathrm{~kg}$ of dead soles were being made. The trawlers soon left these areas to trawl for fish in better condition. 'The highest mortalities were therefore probably similar to those recorded in 1929 , although it is difficult to make an accurate comparison on the basis of the small amount of information available. 
Considering the distribution of dead fish in the three years (Fig. 7) mortalities appear to have occurred over a much more restricted area in 1929 than on either of the subsequent occasions. However, in view of the high mortalities which took place in 1947 , it is perhaps surprising that the most extensive spread of the area of mortalities was found in 1963. A comparison of VAux's hydrographical data for 1947 with that given by ELLETT in 1963 shows that a major difference between the two

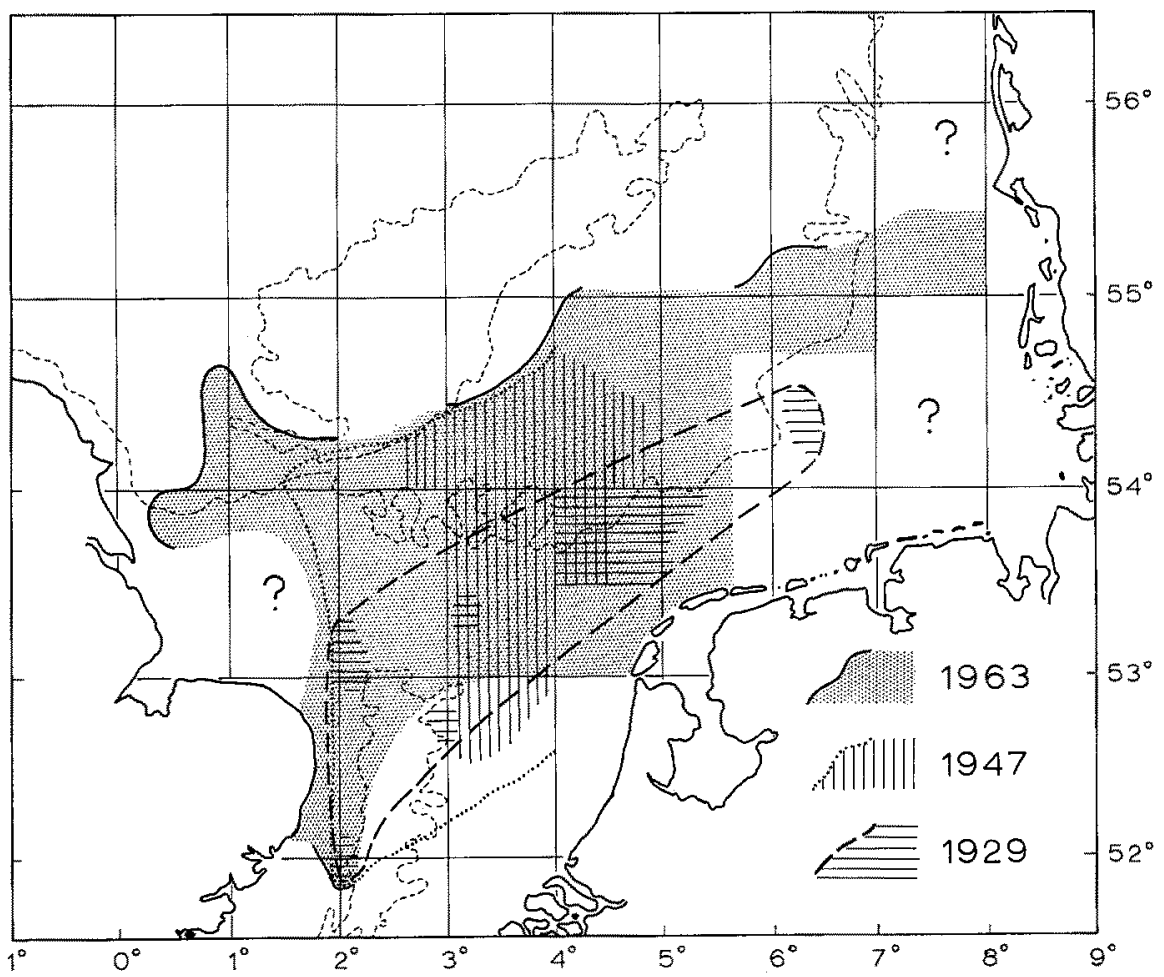

Fig. 7: Comparison of the reported distribution of dead fish in 1929, 1947 and 1963

years was the rapidity of cooling of the sea off the continental coasts; the fall in temperature was much more rapid in 1947; many fish apparently were trapped in the cold waters and killed. In 1963 the situation developed more slowly and the fish were probably better able to avoid the cold waters; however, the low temperatures were maintained for a long time this year, and prolonged exposure to these temperatures appears to have resulted in some mortalities over a wider area.

In discussing the distribution of the dead fish, both LUMBY \& ATKINSON, and SIMPSON, considered that exposure to water of $0^{\circ} \mathrm{C}$ or colder was probably a major cause of the deaths in 1929 and 1947, but this theory presented difficulties since the mortalities were reported over wide areas which had never been covered by waters of such low temperatures. For both 1929 and 1947 these authors attempted to explain this widespread distribution by the passive drift of dead fish in the tidal currents. 
Even so, many dead fish were found "upstream" of the cold water masses, and to account for this, it was suggested that such fish must have actively migrated to these positions before finally dying. However, it seems more likely that the fish were sensitive to prolonged exposures to temperatures higher than $0^{\circ} \mathrm{C}$, and that this was the cause of the wide dispersion of mortalities.

\section{THE CAUSES OF DEATH}

It has been assumed that the majority of mortalities which were reported were caused by the low sea temperatures, particularly for the soles. Little is known of the physiological effects upon teleosts of prolonged exposure to low temperatures. The experiments of Doudoroff $(1942,1945)$ and of BRETT (1952) have shown that it may take a week or longer before fish finally die at a temperature just below their incipient lower lethal temperature; these authors postulated that death was related to osmotic imbalance. Similarly, in experiments measuring the balance of ions in the freshwater carp (Cyprinus carassius) WIKGREN (1953) demonstrated that subjection to low temperatures led to excessive loss of ions, below a critical temperature. It was not known whether death at these low temperatures was caused directly by a breakdown in the mechanism of salt-regulation, or whether the primary lesions occurred elsewhere.

The cod in the Barents Sea often appear to be limited in their distribution by temperatures of about $2^{\circ} \mathrm{C}$ (LeE 1952, Maslov 1944, Saetersdal 1956). Many cod caught below this limiting temperature were found to have an abnormally high bloodsalt content, and it has been suggested that such fish had reached a physiological limit at $2^{\circ} \mathrm{C}$, the fish caught below this limit being in a state of osmotic imbalance (WoodHEAD \& WOODHEAD 1959). Unfortunately, this view has been challenged by ELIASSEN et al. (1960), who repeated the observations on Barents Sea cod, with similar results, but considered that the higher salt content in the blood of cod caught below $2^{\circ} \mathrm{C}$ simply indicated a "small shift in osmolarity" in adapting to a lower temperature. They believed that hypotonicity of the blood was largely maintained.

In view of these earlier studies it was considered that it would be of great interest to determine the blood-salt content of the species of fish which were killed during the winter of $1962 / 63$. Serum samples were therefore collected from fish caught at different temperatures on board the research vessels "Clione" and "Platessa". The fish were taken directly from the ship's deck as they were released from the cod-end of the trawl; each fish was carefully wiped down with cloths, its tail cut off and blood taken from the caudal artery into a chemically clean plastic tube; the blood was allowed to clot. It was intended to decant the serum for storage in a deep-freeze, but due to some misunderstanding the whole clotted samples were deep-frozen; this treatment later caused considerable haemolysis from fragmented red corpuscles when the samples were thawed and centrifuged before analysis. This regrettable error must have contributed to the scatter of results; nevertheless the serum samples taken from fish caught at different temperatures were directly comparable, since they were all treated in the same manner. Sodium analyses were made on diluted serum samples, using a Unicam SP 900 Flame Spectrophotometer. 
The largest series of serum samples was obtained from cod caught between $+4^{0} \mathrm{C}$ and $-0.3^{\circ} \mathrm{C}$. The results are shown in Figure 8 ; it can be seen that increasing numbers of cod caught below a temperature of about $2^{\circ} \mathrm{C}$ had a high serum sodium content, and in some samples taken from cod caught near $0^{\circ} \mathrm{C}$, the sodium content of the serum was nearly double the values observed at temperatures of $2^{\circ}$ to $4^{\circ} \mathrm{C}$. These high levels

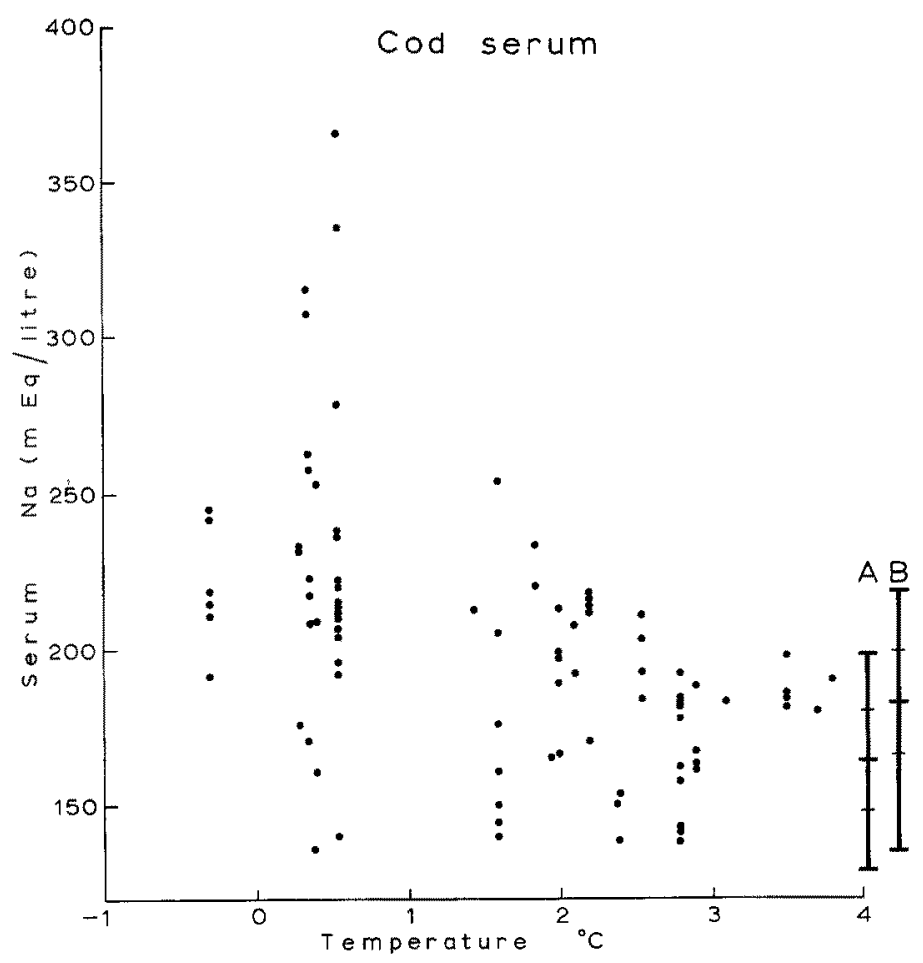

Fig. 8: Serum sodium values for cod caught at different temperatures, winter 1963. A: Range, mean and standard deviation for seventeen serum samples from cod caught between $12^{\circ}$ and $14.5^{\circ} \mathrm{C} ; \mathrm{B}$ : Range, mean and standard deviation for seventy plasma samples from cod caught in the Barents Sea between $2^{\circ}$ and $5^{\circ} \mathrm{C}$

appeared to be greater than the slight shifts in osmolarity suggested by ELIASSEN et al. (1960); it did not seem that hypotonicity was being maintained. In fact, it was probable that the sodium content of the blood of these cod was approaching lethal levels.

For comparison with the winter cod serum samples, the range, mean and standard deviation for seventeen serum samples collected from North Sea cod caught between $12^{\circ}$ and $14.5^{\circ} \mathrm{C}$ are shown in Figure 8; the range, mean, and standard deviation for further seventy plasma samples collected from cod, caught between $2^{\circ}$ and $5^{\circ} \mathrm{C}$ in the Barents Sea, are also included in this figure.

Similar results were obtained from analyses of the blood serum taken from soles caught between $4^{\circ}$ and $1.4^{\circ} \mathrm{C}$ (Fig. 9). The series of sole samples was not so extensive as that of the cod, since live soles were not captured at the lowest temperatures fished. 
Sera from soles caught at $3^{\circ} \mathrm{C}$ or lower gave some very high sodium values, although, surprisingly, the four samples collected from fish at the lowest temperatures had sodium levels which were little higher than the normal for fish taken above $3^{\circ} \mathrm{C}$. The range, mean and standard deviation for a further twelve samples of sole sera collected at $12^{\circ}$ to $14.5^{\circ} \mathrm{C}$ have also been included in Figure 9.

Serum samples from plaice showed little change until temperatures of $0^{\circ} \mathrm{C}$ were approached, when a few of the fish had a high serum sodium content. Blood samples

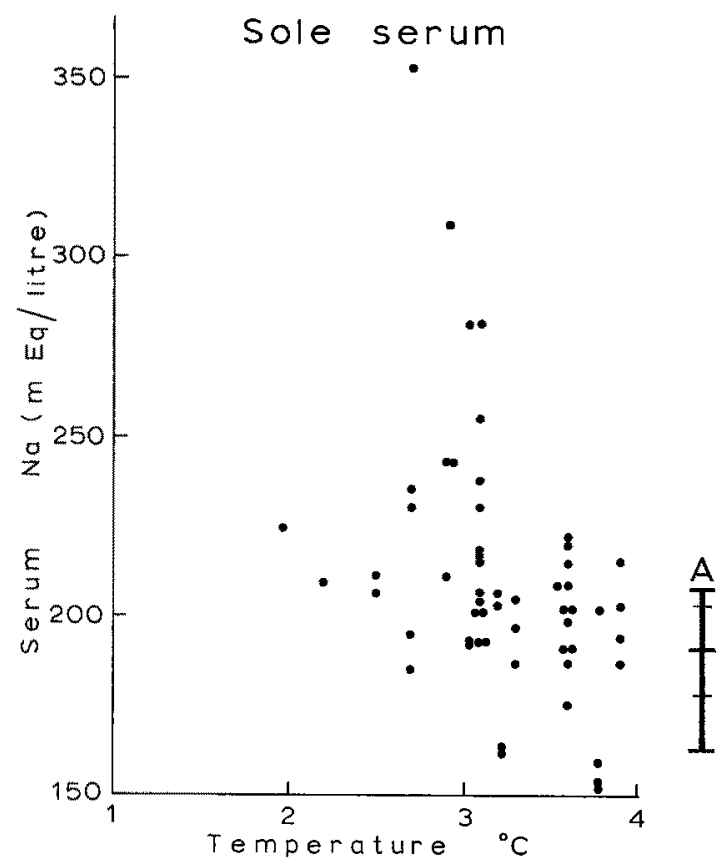

Fig. 9: Serum sodium values for soles caught at different temperatures, winter 1963. A: Range, mean and standard deviation for twelve serum samples from soles caught between $12^{\circ}$ and $14.5^{\circ} \mathrm{C}$

from brill, turbot, whiting and flounder were also analysed, but the samples were either too few to give significant results, or else no fish were taken at low temperatures. For instance, only two flounders were caught below $3^{\circ} \mathrm{C}$, although one of them, at $0^{\circ} \mathrm{C}$, had a high level of serum sodium.

The values obtained from the serum sodium analyses show considerable scatter, and whilst some fish had high levels of sodium at a particular temperature, other fish of the same species caught at that temperature gave values falling within the normal range. Apart from individual variability, a number of factors may contribute to the scatter of the results; it must be emphasised that the duration of exposure to low temperatures was probably very important, since fish which had been in the cold water for only a short period might show little change in their blood salt-content, whilst sera from those fish which had been at low temperatures for a longer time would be expected to have higher values. It was not known for how long individual fish had been at 
a particular temperature, yet it was apparent from the timing of mortalities both in 1947 and 1963 that the duration of exposure to low temperatures was a critical feature in killing the fish.

The results of these analyses would suggest that the limit for prolonged exposure to low temperatures may be about $3^{\circ} \mathrm{C}$ for sole, $2^{0} \mathrm{C}$ for cod, and possibly about $0^{0} \mathrm{C}$ for plaice. The figure of $2^{\circ} \mathrm{C}$ for North Sea cod shows close agreement with the results previously reported for cod in the Barents Sea (WoOdHEAd \&. WoOdHEAD 1959) and the results for the soles are also in good agreement with the distribution of dead fish in the winter of 1963; dead soles were reported throughout most of the area of the North Sea covered by water of $3^{\circ} \mathrm{C}$ or less and, if these serum samples were typical, a large percentage of the living soles must also have been in a state of ionic imbalance. The rather less reliable limit of about $0^{\circ} \mathrm{C}$ for plaice also corresponds well with the report of SMIrH (1948), who found only $43 \%$ mortality in plaice held in spawning ponds at the Port Erin Laboratory in 1947, despite the fact that the temperature in the ponds fell below $0^{\circ} \mathrm{C}$ for about four weeks. BODDEKE (1963) also reported that plaice and flounders survived in a stagnant saltwater lake, Veerse Meer, although it was iced over for some months.

\section{SKIN-INFECTION IN FLATFISH}

It has been assumed that most of the mortalities recorded were associated with the low sea temperatures but some members of the flatfish species were undoubtedly killed by an infection of the skin, which first appeared as small patches or sores about a centimetre in diameter. The sores occurred on both dorsal and ventral surfaces of the fish, and frequently appeared first on the marginal fins; in the sole they were conspicuously white. The sores later increased in size and the patches of skin fell away, the infection gradually penetrating deeply into the muscle tissues of the fish, causing their breakdown and the eventual death of the fish. Soles in particular were attacked by this disease, but many dabs and plaice with sores were also mentioned in reports and occasionally turbot and brill; although flounders were caught in small numbers in the same areas they were never reported as being infected. The infection occurred throughout all of the southern North Sea, including areas where only a low level of mortality had occurred. The fishing reports mentioned the "white spots" or sores more frequently towards the end of the cold period, particularly in the Silver Pits and the area between the Yorkshire coast and the south-west Dogger Bank where mortalities still tended to increase after the coldest period was past.

The nature of this infection is not known at present, but it was probably bacterial. In considering the physiological effects of low temperatures upon cod in the Barents Sea, it has been suggested that mucus production may be inhibited (WooDHEAD \& WOODHEAD 1959): if this also occurred in the flatfish, the scale-bed could readily be invaded by bacteria and the sores develop. It is of interest that soles with these white sores were frequently reported amongst the dead fish during both of the cold winters of 1929 and 1947 (Lumby \& Atkinson 1929, Simpson 1953). Simpson considered that the sores could have been first caused by physical damage due to 
freezing of the tissues of fish caught in the coldest areas, and that these lesions would then be invaded by bacteria. However, this would seem an unnecessary complication, since many flatfish with sores were caught within areas many miles from those nearest cold water masses which might possibly have induced freezing. A simpler explanation would be that the sores were not caused by freezing and physical damage to the tissues, but that the infection was effective over a much wider area than assumed by Simpson, attacking fish already weakened by the effects of the low temperatures.

\section{DISCUSSION}

Since the death of many of the flatfishes was undoubtedly associated with the "white spot" infection of the skin, it is appropriate to consider whether infection with other forms of disease may not have killed the rest of the fish. It seems probable that other diseases would have occurred, although there is no direct information on this point. However, it is thought unlikely that all mortalities could be accounted for in this manner, rather than by the direct effects of low temperatures. The sole reaches the northern limit of its distribution in the southern North Sea, and would be expected to be particularly sensitive to the effects of low temperatures. This was evident during the winter of 1963 when soles reacted to the low temperatures by moving out of the coldest areas (WOODHEAD 1964b). This species also suffered the highest mortalities. It might therefore be expected that most of these deaths were caused directly by low temperatures, particularly as mortalities were highest in the coldest regions. In 1947 dead soles were reported in even larger numbers, and over wide areas within the coldest waters, mortalities of $50 \%$ to $100 \%$ were reported. It would be surprising if such catastrophic mortalities had been due to a number of different infections, and not due to temperature. It seems more likely that the temperatures had fallen below the incipient lethal limits of the fish and that some physiological mechanism was breaking down. This was illustrated by the high serum sodium levels in soles below $3^{\circ} \mathrm{C}$, suggesting loss of the capacity for ionic regulation (though it is not known whether the primary lesion occurred in some part of the osmoregulatory mechanism, or elsewhere).

Some of the soles in such poor physiological condition might well have then become secondarily infected with diseases and died. In areas where mortalities were low, and also more generally when temperatures were again rising, reports of dead soles with skin infections were much more frequent than during the initial period when high mortalities were occurring. It seems likely that soon after temperatures started to rise the fish were able to resume normal physiological regulation, but that those which had previously become infected would continue to die for some time and still be recorded in fishing reports.

The considerations applied to the death of soles during the winter also apply to some extent to other species which were killed. It is concluded that a primary cause of death was due to the effects of the low temperature upon the physiology of the fish, although many fish also finally died from secondary infections. 


\section{SUMMARY}

1. During the cold winter of $1962 / 63$ fish mortalities were frequently reported over much of the North Sea to the south of the Dogger Bank. The sole populations certainly suffered the highest mortalities, but dead cod, plaice, whiting, dabs, turbot, brill and conger eel were also reported.

2. Fish began to die towards the end of February, and the numbers increased to a maximum in mid-March, after which they gradually decreased until reports ceased by mid-April. The development of mortalities was compared with the sea temperatures at the time.

3. The mortalities were on a large scale but not as great as previously reported for the cold winter of 1946/47; they may have been as heavy as those in 1928/29. Their distribution was more widespread than in either 1929 or 1947.

4. Analysis of fish blood serum showed abnormally high sodium levels in many fish caught in the colder waters. In some individuals the salt content appeared to approach lethal levels, but it was not known whether salt imbalance was the primary cause of death.

5. Flatfish were also attacked by a skin infection which certainly contributed to the deaths of many of these fish during the cold period.

\section{ACKNOWLEDGMENTS}

I am most grateful to the trawler officers and owners of trawlers who have co-operated in this survey and to the District Inspectors of Fisheries in Grimsby and Lowestoft, Mr. W. WIILIAMs and Mr. G. J. Y. Thorpe, and their respective staffs for their help in circulating the enquiry forms and interrogating trawler officers. Mr. V. J. BYE also carried out a valuable independent enquiry amongst trawler officers. The help of the Deputy Director of Fisheries Research, Mr. R. J. H. BEvERTON, in setting aside research vessel time for surveys and collection of material is gratefully acknowledged. I am also pleased to thank Mr. D. J. ELLETT for allowing me to consult his paper before publication, and Dr. R. BodDeke for permission to quote his paper.

\section{LITERATURE CITED}

BODDEkE, R., 1963. Influence of the severe winter 1962-63 in the Dutch coastal waters. I.C.E.S. Near Northern Seas Committee Paper No. 119, 1-3.

BretT, J. R, 1952. Temperature tolerance in young Pacific salmon, genus Oncorbynchus. J. Fish. Res. Bd. Can. 9, 265-323.

Dannevig, A., 1930. The death of fish in very cold winters. J. Cons. 5, 194-196.

Doudororf, P., 1942. The resistance and acclimatization of marine fishes to temperature changes. I. Experiments with Girella nigricans (Ayres). Biol. Bull. mar. biol. Lab., Woods Hole 83, 219-244.

- 1945. The resistance and acclimatization of marine fishes to temperature changes. II. Experiments with Fundulus and Atherinops. Biol. Bull. mar. biol. Lab., Woods Hole 88, 194-206.

Elyassen, E., Leivestad, H. \& Molier, D., 1960. The effect of low temperatures on the freezing point of plasma and on the potassium/sodium ratio in the muscles of some boreal and subarctic fishes. Arbok Univ. Bergen, Mat.-Naturv. Ser. Nr. 14, 1-24. 
ElLETT, D. J., 1963. Surface temperatures in the southern North Sea, January-March 1963. I.C.E.S. Hydrographical Committee Paper No. 115, 1-7.

FINCH, R. H., 1917. Fish killed by the cold wave of February 2-4, 1917, in Florida. Mon. Weath. Rev., Wash. 45, 171.

GallowAY, J. C., 1941. Lethal effect of the cold winter of 1939-40 on marine fishes at Key West, Florida. Copeia No. 2, 118-119.

Johansen, A. C., 1929. Mortality amongst porpoises, fish, and the larger crustaceans in the waters around Denmark in severe winters. Rep. Danish biol. Sta. 35, 63-97.

Jordan, D. S. \& Everman, B. W., 1902. American food and game fishes. Doubleday, New York, 572 pp.

Laevastu, T., 1962. Water types in the North Sea and their characteristics. Hawaii Inst. Geophys. 24, 1-3.

LeE, A. J., 1952. The influence of hydrography on the Bear Island cod fishery. Rapp. Cons. Explor. Mer 131, 74-102.

LumbY, J. R. \& Atkinson, G. T., 1929. On the unusual mortality amongst fish during March and April, 1929, in the North Sea. J. Cons. 4, 309-332.

MasLov, N. A., 1944. [The bottom-fishes of the Barents Sea and their fisheries.] (In Russian.) Trudy PINRO 8, 3-186.

MrLler, E. M., 1940. Mortality of fishes due to cold on the southeast Florida coast, 1940. Ecology 21, 420-421

SAETERSDAL, G., 1956. [Fisheries research in northern waters - study items and results.] (In Norwegian.) Forskning og Fiske Nr. 1, 1-23.

Simpson, A. C., 1953. Some observations on the mortality of fish and the distribution of plankton in the southern North Sea during the cold winter, 1946-1947. J. Cons. 19, $150-177$.

SMITH, W. C., 1948. Effect of severe winter conditions of 1946-1947 on fish and lobsters at Port Erin. Rep. Mar. biol. Sta. Pt. Erin for 1945-1947, 30-35.

Storey, M. \& Gudger, E. W., 1936. Mortality of fishes due to cold at Sanibel Island, Florida, 1886-1936. Ecology 17, 640-648.

VAux, D., 1953. Hydrographical conditions in the southern North Sea during the cold winter of 1946-1947. J. Cons. 19, 127-149.

WIKGREN, B.-J., 1953. Osmotic regulation in some aquatic animals with special reference to the influence of temperature. Acta zool. fenn. No. 71, 1-93.

Wirlcox, J., 1888. Fish killed by cold along the Gulf of Mexico and coast of Florida. Bull. Bur. Fish., Wash. 6 (1886).

Woodhead, P. M. J., 1964a. The death of fish and sublittoral fauna in the North Sea and the English Channel during the winter of 1963. J. Anim. Ecol. 33, 169-173.

- 1964b. Changes in the behaviour of the Sole, Solea vulgaris, during cold winters, and the relation between the winter catch and sea temperatures. Helgol. Wiss. Meerestinters. 10 (in press).

- \& WOODHEAD, A. D., 1959. The effects of low temperatures on the physiology and distribution of the cod, Gadus morhua L., in the Barents Sea. Proc. zool. Soc. Lond. 133, $181-199$.

\section{Discussion following the paper by WoODHEAD}

Møller Christensen: I would like to know about the efficiency of British trawlers. Otherwise, the mortality of 5,10 and 15 fish per trawl does not mean very much.

WOODHEAD: I agree that the trawl is not necessarily the most efficient sampling instrument to chart the distribution of dead fish; it might pass over many bodies lying on the bottom. Nevertheless, it was considered that it still provided useful information about the areas of highest mortalities and the time sequence of events; it could be used for comparisons with other years since the same gear had been used for sampling throughout the period. Does this answer your point? 
Morler Christensen: No, not really. Let us say we have 15 dead fish in a trawl haul. It is not the same whether you have 500 live fish in the haul at the same time or 2,000 or 5,000 . This is what I am driving at - to see some sort of percentage.

WOODHEAD: Yes, I am with you. If you are raising the point that in general the mortalities were not particularly high, I agree with you there. Nevertheless, in those areas where mortalities were high, the trawls in fact did get quite large catches. Thirty kilograms of dead soles is definitely a large catch, so they have, I imagine, a reasonable level of efficiency monitoring the mortalities, although there would certainly be more dead fish than they actually caught.

Boolootian: You have said that most of the fish may have been killed by the cold, yet the possibility of a bacterial infection having caused death has not been ruled out. Have you attempted any laboratory studies where similar bacterial infections could be induced at low temperatures?

WOODHEAD: No. We have no tank facilities at Lowestoft for keeping fish at any temperature for this type of experiment. I agree that it would be a valuable approach.

Prosser: The rise in serum sodium might indicate a failure of the sodium secreting mechanisms of the gills. There may also be a failure of selective permeability in general; this could result in potassium leakage from tissue cells. Have you any measurements on serum potassium?

WOODHEAD: The blood was badly haemolyzed by deep-freezing (as mentioned above) so that potassium analyses were not possible. We have not completed our work on these North Sea fish yet, but in joint work with my wife we found a similar situation in cod in the Arctic. The fish were limited in distribution at about $2^{\circ} \mathrm{C}$ (as in the North Sea) and below this temperature had abnormally high plasma sodium, potassium, chloride and a lowered freezingpoint depression. Histological examination of the gills of these fish showed increased numbers of the so-called "chloride secretory cells", which showed many signs of hyperactivity. On the other hand, most of the mucus was missing from the gills, and it was thought that ions from sea water would therefore be passing into the circulation while there was increased activity by the "chloride secretory cells" in an attempt to get rid of these extra salts. Gills were collected from the North Sea fish but have not yet been examined microscopically.

Prosser: Can you correlate sensitivity of different species to cold in the winter of 1962/63 with their geographic ranges?

WOODHEAD: Yes. The soles in particular may be called Mediterranean species and reach the northern end of their range in the North Sea. Gurnards too are characteristically a warmwater species.

VAUCK: Es ist für gewisse Fragestellungen von Interesse zu wissen, ob überhaupt und wenn, wann, welche toten Fische zur Oberfläche aufschwimmen.

WOODHEAD: Only Conger eels in the inshore areas; these were frequently reported as floating dead at the surface, but we never heard of any other species. Offshore we were working in 40 to 60 meters of water, and we never found any dead fish at the surface nor were any reported. 